\title{
Perencanaan Modifikasi Rangka Busur Baja pada Jembatan Pemali disertai Damper sebagai Longitudinal Stopper
}

\author{
Bintang Mahardhika dan Endah Wahyuni \\ Jurusan Teknik Sipil, Fakultas Teknik Sipil dan Perencanaan, Institut Teknologi Sepuluh Nopember (ITS) \\ Jl. Arief Rahman Hakim, Surabaya 60111 Indonesia \\ e-mail: endahwahyuni.its@gmail.com
}

\begin{abstract}
Abstrak - Jembatan Pemali merupakan jembatan yang terletak di Kota Brebes. Jembatan ini menjadi akses penting yang menghubungkan antara Kota Semarang dan Kota Jakarta. Jembatan Pemali sering mengalami perbaikan dalam segi struktural setiap bulannya, hal ini diakibatkan oleh semakin padat volume kendaraan terutama truk dengan muatan berat. Permasalahan ini yang melatarbelakangi pembangunan Jembatan Pemali yang baru agar menunjang dalam sarana transportasi. Penelitian ini memodifikasi Jembatan Pemali menjadi sistem busur rangka baja. Jembatan didesain dengan tinggi 18 meter, bentang 100 meter dan lebar 9 meter. Penelitian ini menggunakan kombinasi pembebanan sesuai SNI T-02-2005 dan SNI 1725-2016. Dengan menggunakan progam bantu SAP2000, kombinasi KUAT 1 (SNI-1725-2016) menghasilkan output gaya yang lebih besar daripada kombinasi lainnya sehingga kombinasi tersebut digunakan untuk menentukan profil rangka atas jembatan. Analisis pengaruh damper dengan tipe Lock-Up Device menggunakan progam bantu SAP2000 dengan kombinasi beban yang menentukan dalam perencanaan damper sebagai longitudinal stopper adalah kombinasi EKSTREM I (SNI1725-2016). Hasil dari analisis dengan progam bantu SAP2000 profil utama yang terbesar pada jembatan busur menggunakan BOX 500x500x25 serta dengan adanya damper struktur utama jembatan mampu mengurangi deformasi sebesar $16 \%$. Dalam merencanakan bangunan bawah jembatan, dilakukan kontrol guling dan geser pada abutment jembatan serta untuk tiang pancang jembatan dilakukan kontrol berdasarkan daya dukung tanah dan tipe material yang digunakan. Dari perencanaan tersebut, didapatkan dimensi abutment 11x11x10 meter serta kebutuhan tiang pancang jembatan 36 buah. Hasil seluruh perhitungan Penelitian ini dituangkan dalam gambar teknik standar.
\end{abstract} Baja.

Kata kunci : Abutment, Damper, Jembatan Busur Rangka

\section{PENDAHULUAN}

$\mathrm{T}$ RANSPOTASI merupakan alat yang sangat penting dalam perkembangan era global saat ini. Salah satu usaha yang menunjang transportasi adalah pembangunan infrastruktur jembatan. Dalam meningkatkan dan menunjang sarana transportasi keadaan jembatan harus dalam kondisi baik [1]. Kondisi jembatan yang kurang baik dapat menghambat kelancaran transportasi serta menimbulkan permasalahan baik material maupun sosial. Contohnya jembatan Pemali sering kali mengalami kerusakan dari segi strukturalnya, sehingga perbaikan pada Jembatan Pemali dapat terjadi setiap bulannya dan menyebabkan kemacetan transportasi.

Jembatan Pemali terletak di wilayah Kota Brebes yang sesuai peta wilayah gempa masuk pada zona gempa 3 [4],
[7]. Jembatan Pemali merupakan jembatan tipe kelas nasional di jalur pantura yang menjadi perbatasan antara Kota Jakarta dan Semarang (lihat Gambar 1). Saat ini terdapat jembatan lama bertipe rangka batang terbuka dengan 2 lajur 2 arah, lebar 9 meter, 2 bentang dan panjang tiap bentang 50,292 meter yang terbagi menjadi beberapa segmen (lihat Gambar 2).

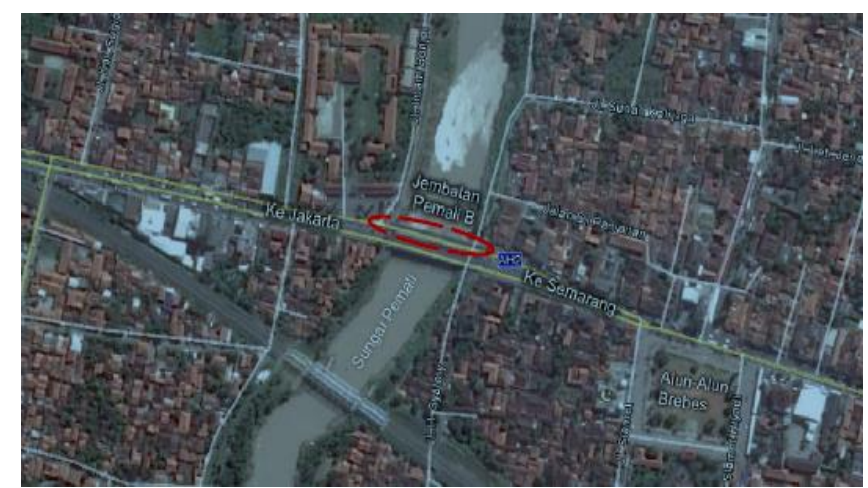

Gambar 1. Lokasi Jembatan Pemali

Dengan meningkatnya volume lalu lintas saat ini, keadaan dari Jembatan Pemali sebagai tipe jembatan kelas nasional sangatlah perlu diperhatikan. Dengan kondisi jembatan yang perlu perbaikan terus menerus kurang bisa melayani volume lalu lintas yang ada. Untuk menghindari kegagalan struktur dalam meningkatkan infrastruktur, dibutuhkan jembatan baru yang selain kuat dalam memikul beban vertikal akibat kendaraan besar juga tahan terhadap gaya gempa pada Zona Gempa 3 [4].

Dalam Penelitian ini direncanakan Jembatan Pemali yang baru dengan konstruksi rangka busur baja. Konstruksi busur rangka baja dinilai lebih efektif untuk jembatan bentang panjang karena bentuk busur mengurangi momen lentur yang ada di lapangan, sehingga penggunaannya lebih efisien daripada gelagar pararel. Kontruksi dari busur baja dipilih karena memiliki kekuatan yang cukup tinggi dengan luas penampang relatif lebih ramping daripada material beton [9].

Pada perencanaannya Jembatan Busur Pemali ini terdiri dari 1 bentang dengan panjang total 100 meter dengan pilar yang ada di tengah Jembatan Pemali diasumsikan tidak ada. Perencanaan modifikasi dengan tipe busur dikarenakan untuk jembatan tipe rangka baja hanya memiliki batas bentang sepanjang 60 meter (lihat Gambar 3) [9]. Pemilihan jembatan busur rangka baja juga disesuaikan dengan lapangan karena kedalaman dasar sungai yang tidak terlau dalam.

Salah satu tambahan pada Jembatan Pemali yang baru adalah pemberian damper dengan jenis LUD (Lock-Up 
Device) sebagai lateral stopper[13]. Damper jenis LUD ini terlihat seperti sejenis dongkrak atau shockbreaker yang diletakkan pada pertemuan antara abutment dan jembatan busur baja. LUD menggunakan cairan khusus (gel silikon) yang menjadi bantalan khusus sebagai damper kontrol pasif (isolasi seismik). Damper jenis LUD ini berfungsi meminimalisir dan meredam pergerakan struktur saat gempa bumi terjadi, selain itu juga sebagai penahan gaya normal akibat rem kendaraan [7].

Dengan adanya Jembatan Busur Pemali ini diharapkan menjadi solusi dalam merancang sebuah jembatan yang kuat secara struktural dengan sistem busur yang dinilai lebih efesien dalam segi material. Dan dari segi estetika menjadi landmark tersendiri bagi Kota Brebes yang bisa meningkatkan perekonomian warga sekitar.

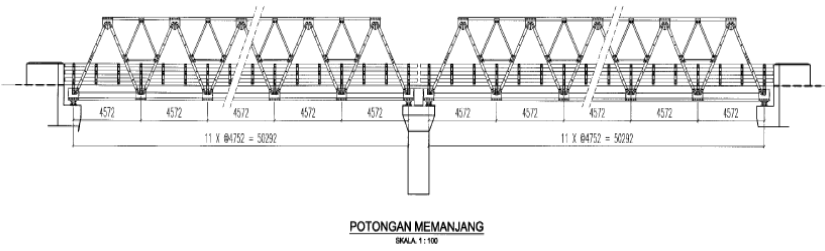

Gambar 2. Kondisi Jembatan Pemali yang ada

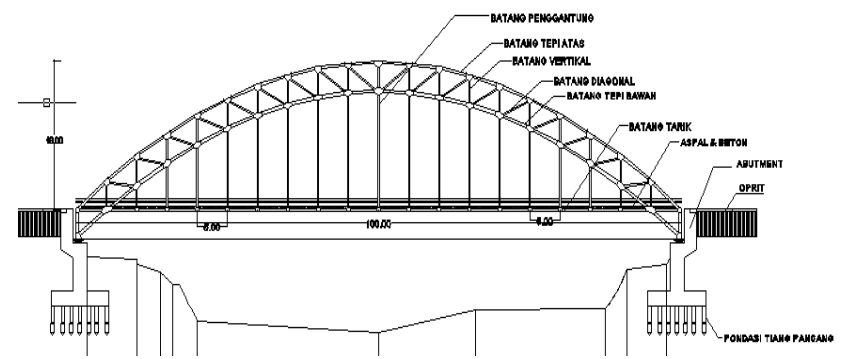

Gambar 3. Tampak Memanjang Jembatan Pemali dengan Rangka Busur Baja

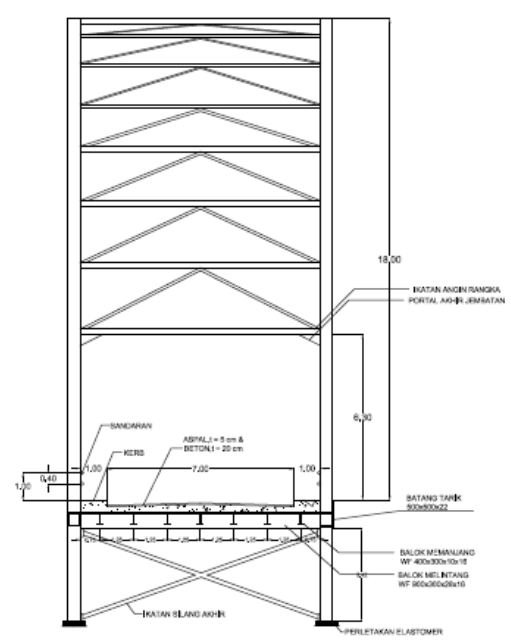

Gambar 4. Tampak Melintang Jembatan Pemali dengan Rangka Busur Baja

\section{METODOLOGI}

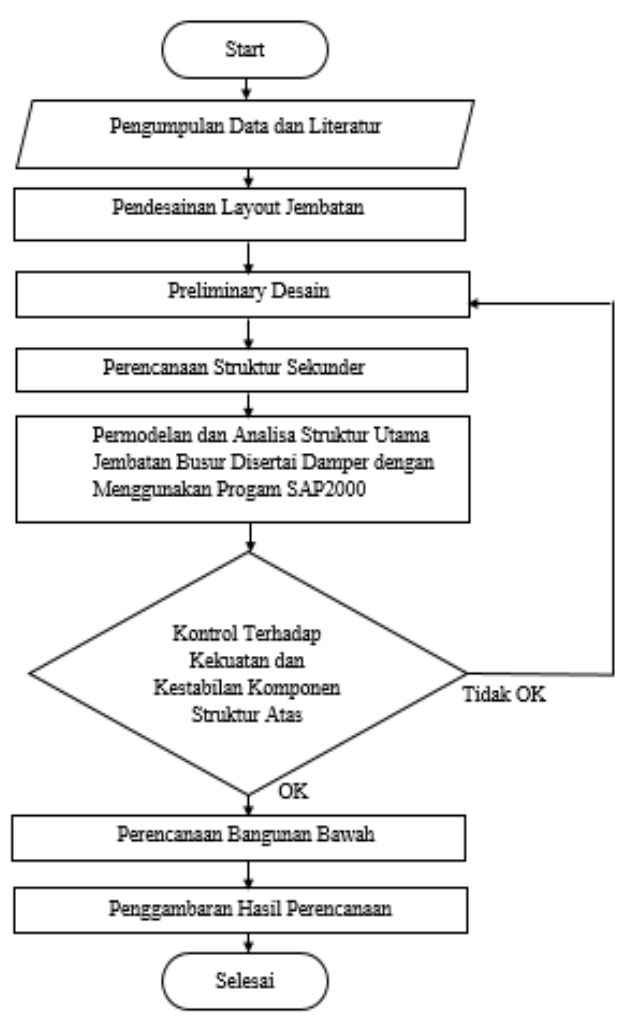

Gambar 5. Diagram Alir

Adapun keterangan dari bagan metodologi di atas adalah sebagai berikut :

\section{A. Studi literatur}

Melakukan studi literatur dengan berpedoman beberapa standar peraturan sebagai bahan pustaka dalam pengerjaan penelitian, antara lain :
a. Bridges Management System (BMS) 1992
b. SNI T-02-2005
c. SNI 03-2847-2002
d. RSNI T-03-2005
e. SNI 03-1729-2002
f. SNI 2833-2008 (gempa jembatan)
g. SNI 1725-2016

\section{B. Pengumpulan data}

Data yang diperlukan antara lain :

- Bentang jembatan : 100 meter

- Data tanah $\quad$ : Standar Penetrasi Test (SPT)

- Lokasi : Kota Brebes

- Ruas Jalan : JKT-SMG/Brebes

- Letak Jembatan : $7.5 \mathrm{~km}$ dari pantai

- Zona wilayah gempa : 3

C. Preliminary Design

a) Penentuan mutu bahan yang digunakan :

- Mutu Beton (f'c) = $24 \mathrm{MPa}$.

- Mutu Baja Tulangan (fy) = $40 \mathrm{MPa}$.

- Struktur utama BJ 50 (fy) = $290 \mathrm{MPa}$.

- Mutu baut sambungan menggunakan ASTM A325 untuk sambungan baut antar profil sedangkan sambungan base plate dengan pondasi menggunakan ASTM A307 [2].

- Mutu las yang digunakan adalah E70xx [2]. 


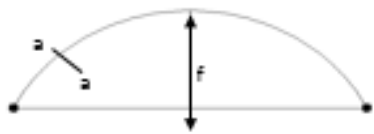

Gambar 6. Tinggi Busur

b) Memperkirakan tebal pelat lantai kendaraan

Pelat lantai yang berfungsi sebagai jalan kendaraan pada jembatan harus mempunyai tebal minimum $t s$, dengan ketebalan $20 \mathrm{~cm}$ [5]. Dengan profil untuk balok memanjang dan balok melintang sebagai berikut :

Balok memanjang WF 400x300x10x16

Balok melintang WF 900x300x28x16.

c) Modelisasi Struktur

Penelitian ini memodelkan Jembatan Busur Pemali dengan menggunakan progam bantu SAP2000. Pemodelan 2 Dimensi untuk mendapatka garis pengaruh pada jembatan busur dan pemodelan 3 Dimensi untuk mendapatkan porfil yang digunakan sesuai kombinasi pembebanan SNI 1725-2016 [5].

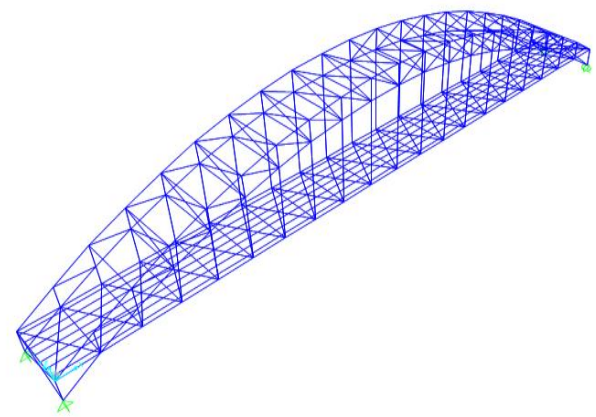

Gambar 7. Pemodelan Jembatan dengan SAP2000

Profil rangka utama menggunakan brosur PT GUNUNG RAJA PAKSI yang memiliki mutu GR 50 A (fy $=345$ Mpa dan fu $=565 \mathrm{Mpa}$ ) [11].

Berikut merupakan rekap profil rangka utama jembatan :

- Batang tepi atas segmen 1 Box $500 \times 500$ x 25

- Batang tepi atas segmen 2 Box 500 x 500 x 22

- Batang tepi atas segmen 3 Box 400 x 400 x 25

- Batang tepi bawah segmen 1 Box 400 x 400 x 16

- Batang tepi bawah segmen 2 Box 400 x 400 x 16

- Batang tepi bawah segmen 3 Box 400 x 400 x 16

- Batang vertikal Box $180 \times 180 \times 8$

- Batang diagonal Box $180 \times 180 \times 10$

- Batang vertikal akhir 500 x $500 \times 19$

- Batang tarik $500 \times 500 \times 22$

- Kolom portal akhir 500 x $500 \times 25$

- Balok portal akhir $500 \times 500$ × 25

- Threadbars diameter $47 \mathrm{~mm}$

d) Perletakaan Jembatan

Jenis perletakkan pada Penelitian ini adalah elastmer dengan brosur dari Freyssinet yang memiliki ukuran 600 x $600 \mathrm{~mm}$ dengan ketebalan $69 \mathrm{~mm}$ [8].

e) Efektifitas Damper

Untuk menentukan desain dari Lock Up Device sebelumnya dicari gaya yang bekerja pada titik pemasangan damper. Kombinasi yang digunakan untuk mencari gaya yang bekerja menggunakan kombinasi pembebanan SNI 1725-2016, dengan koefisien beban
(Ekstrem I) dan diinput kombinasi ke progam bantu SAP2000 untuk memperoleh gaya yang bekerja pada pemasangan damper [5].

Tabel 1.

Gaya yang Bekerja pada Titik Pemasangan Damper Jembatan

\begin{tabular}{|c|c|c|c|}
\hline Frame & Joint & OutputCase & F1 \\
\hline Text & Text & Text & Kgf \\
\hline 20 & 21 & EKSTREM 1 & $-701606,72$ \\
\hline 149 & 21 & EKSTREM 1 & 656737,17 \\
\hline 209 & 21 & EKSTREM 1 & $-1728,51$ \\
\hline 211 & 21 & EKSTREM 1 & 41795,75 \\
\hline 212 & 21 & EKSTREM 1 & 0 \\
\hline 279 & 21 & EKSTREM 1 & 4802,3 \\
\hline 40 & 44 & EKSTREM 1 & $-700586,4$ \\
\hline 75 & 44 & EKSTREM 1 & 655824,62 \\
\hline 148 & 44 & EKSTREM 1 & $-1714,61$ \\
\hline 211 & 44 & EKSTREM 1 & 41671,55 \\
\hline 213 & 44 & EKSTREM 1 & 0 \\
\hline 280 & 44 & EKSTREM 1 & 4804,84 \\
\hline \multicolumn{4}{|c|}{ Max } \\
\hline \multicolumn{4}{|c|}{ min } \\
\hline
\end{tabular}

Sehingga dari gaya tersebut dapat ditentukan jenis damper yang akan digunakan pada jembatan adalah sebesar 2000 Kip. Efektifitas damper dalam mereduksi gaya dan displacement jembatan dapat dilihat pada Tabel 2.2.

Tabel 2.

Efektifitas Damper

\begin{tabular}{|c|l|l|r|r|c|}
\hline TABLE: Joint Displacements & & & & \\
\hline Joint & \multicolumn{1}{|c|}{ OutputCase } & CaseType & U1-ND & U1-D & selisih \\
\hline Text & Text & Text & m & m & $\%$ \\
\hline 21 & beban rem & LinStatic & 0,002362 & 0,001983 & 16,04572396 \\
\hline 21 & gempa & Combination & 0,030904 & 0,025868 & 16,29562516 \\
\hline 21 & $1,1 \mathrm{D}+2$ SD + 1Q + 0,3TB & Combination & 0,113896 & 0,09534 & 16,29205591 \\
\hline 44 & beban rem & LinStatic & 0,00117 & 0,000973 & 16,83760684 \\
\hline 44 & gempa & Combination & 0,030917 & 0,025877 & 16,30171103 \\
\hline 44 & $1,1 \mathrm{D}+2$ SD + 1Q + 0,3TB & Combination & 0,113508 & 0,095005 & 16,30105367 \\
\hline \multicolumn{5}{|l|}{ average displacement } \\
\hline
\end{tabular}

Hasil analisis pada progam SAP2000 penggunaan damper sebagai lateral stopper mempengaruhi pengurangan maksimum sebesar $16 \%$.

f) Sambungan Jembatan

Sambungan yang digunakan pada Penelitian ini adalah sambungan baut tipe friksi [2].

Sambungan Balok Memanjang dan Balok Melintang Profil Balok Memanjang WF 400x300x10x16 Fy : $250 \mathrm{MPa}$ fu $: 410 \mathrm{MPa}$ Es $: 200000 \mathrm{MPa}$ d $: 390 \mathrm{~mm} \quad$ B $: 300 \mathrm{~mm} \quad$ tw $: 10 \mathrm{~mm}$

Vu maksimum : $32051.53 \mathrm{Kg}$ tf $: 16 \mathrm{~mm}$

Pelat sambung siku 120x120x11 BJ 50

\section{Baut tipe A325}

Diameter baut $(\mathrm{db}) \quad=20 \mathrm{~mm}$

Gaya tarik minimum $\quad=14500 \mathrm{Kg}$

Jumlah bidang geser $(\mathrm{m})=2$

$$
\begin{array}{ll}
\text { Phi }(\varnothing) & =1 \text { (lubang standar) } \\
\mu & =0.35 \text { (permukaan bersih) }
\end{array}
$$

Kekuatan Rencana Baut Tipe Gesek (Friction Type)

Kuat geser $(\varnothing V n)=\emptyset \cdot 1,13 \cdot \mu \cdot m . T_{b}[10]$

$$
\begin{aligned}
& =1 \cdot 1,13 \cdot 0,35 \cdot 2 \cdot 14500 \\
& =11469,5 \mathrm{Kg}
\end{aligned}
$$


Jumlah Baut $(\mathrm{n}) \quad=\frac{V u}{\emptyset V n}=\frac{32051.53}{11469,5}=2,79 \approx 3$ buah

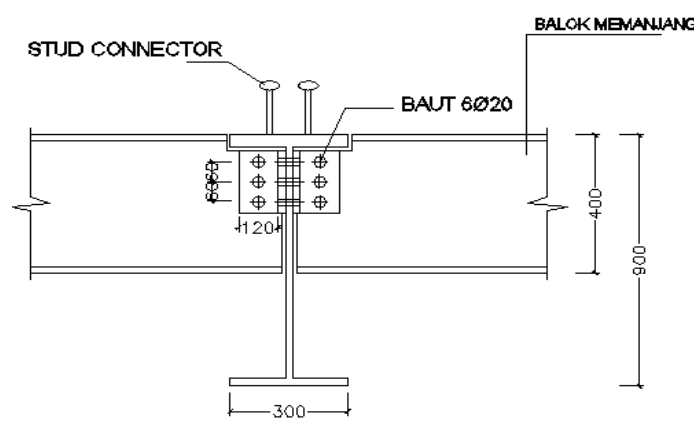

Gambar 8. Sambungan Balok Memanjang ke Balok Melintang

\section{Profil Balok Melintang WF 900x300x16x28}

Fy : $250 \mathrm{MPa}$ fu : $410 \mathrm{MPa}$ Es : $200000 \mathrm{MPa}$

d : $: 900 \mathrm{~mm} \quad$ B $: 300 \mathrm{~mm} \quad$ tw $: 28 \mathrm{~mm}$

tf $\quad: 16 \mathrm{~mm}$

Vu maksimum : $32051.53 \mathrm{Kg}$

Pelat sambung siku 120x120x11 BJ 50

\section{Baut tipe A325}

Diameter baut $(\mathrm{db}) \quad=20 \mathrm{~mm}$

Gaya tarik minimum $\quad=14500 \mathrm{Kg}$

Jumlah bidang geser $(\mathrm{m})=1$

Phi $(\varnothing) \quad=1$ (lubang standar)

$\mu \quad=0.35$ (permukaan bersih)

Kekuatan Rencana Baut Tipe Gesek (Friction Type)

Kuat geser $(\varnothing V n)=\emptyset \cdot 1,13 \cdot \mu \cdot m \cdot T_{b}[10]$

$$
\begin{aligned}
& =1 \cdot 1,13 \cdot 0,35 \cdot 1 \cdot 14500 \\
& =5734,75 \mathrm{Kg}
\end{aligned}
$$

Jumlah Baut $(\mathrm{n})=\frac{V u}{\emptyset V n}=\frac{32051.53}{5734,75}=5,589 \approx 6$ buah

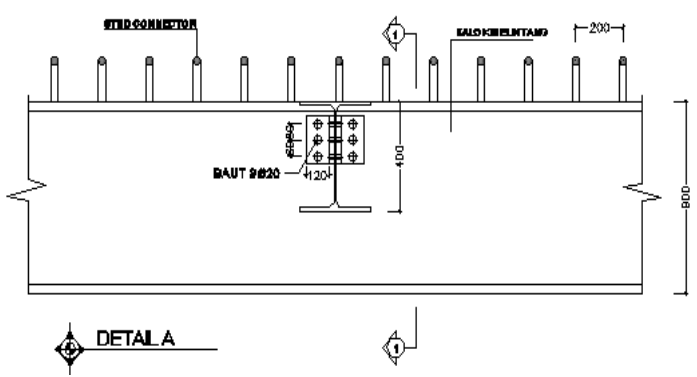

Gambar 9. Sambungan Balok Melintang ke Balok Memanjang

Jarak Pemasangan Baut

Syarat : $3 \mathrm{db} \leq \mathrm{S} \leq 15 \mathrm{tp}$ atau $200 \mathrm{~mm} \mathrm{[10]}$

$1.5 \mathrm{db} \leq \mathrm{S} 1 \leq(4 \mathrm{tp}+100)$ atau $200 \mathrm{~mm}[10]$

maka :

- $3 d_{b} \leq S \leq 15 t_{P}$ atau $200 \mathrm{~mm}$

$3.20 \leq S \leq 15.12$ atau $200 \mathrm{~mm}$

dipakai $S=60 \mathrm{~mm}$

- $1.5 d_{b} \leq S \leq\left(4 t_{P}+100\right)$ atau $200 \mathrm{~mm}$

$1.5 .20 \leq S \leq(4.10+100)$ atau $200 \mathrm{~mm}$

- $\quad 30 \leq S \leq 144$ atau $200 \mathrm{~mm}$

Dipakai $\mathrm{S} 1=30 \mathrm{~mm}$

\section{g) Abutment Jembatan}

Berat sendiri dari abutment jembatan ditambah tanah dibelakangnya dibagi menjadi beberapa segmen. Pembagian segmen tersebut dapat dilihat pada Gambar 10 .

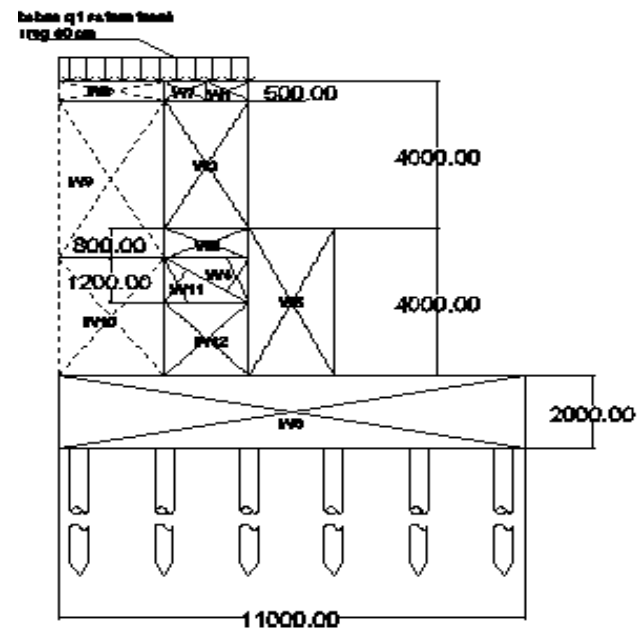

Gambar 10. Sketsa Pembagian Beban pada Abutment Jembatan dan Tanah dibelakang Abutment

Pembagian segmen tersebut untuk mendapatkan berat total dari abutment dan tanah dibelakangnya. Perhitungan dapat dilihat pada Tabel 3 .

Tabel 3.

\begin{tabular}{|c|c|c|c|c|c|c|c|}
\hline kode luasan & b & h & bentuk & luas & lebar & $\gamma$ & berat \\
\hline & $(\mathrm{m})$ & $(\mathrm{m})$ & & $(\mathrm{m} 2)$ & $(\mathrm{m})$ & $(t / m 3)$ & (ton) \\
\hline W1 & 1 & 0,5 & & 0,5 & 11 & 2,4 & 13,2 \\
\hline $\mathrm{W} 2$ & 2 & 4 & & 8 & 11 & 2,4 & 211,2 \\
\hline W3 & 2 & 0,8 & & 1,6 & 11 & 2,4 & 42,24 \\
\hline W4 & 2 & 1,2 & & 1,2 & 11 & 2,4 & 31,68 \\
\hline W5 & 2 & 5,5 & & 11 & 11 & 2,4 & 290,4 \\
\hline W6 & 14 & 2 & & 28 & 11 & 2,4 & 739,2 \\
\hline W7 & 1 & 0,5 & & 0,5 & 11 & 1,7 & 9,35 \\
\hline W8 & 4,5 & 0,5 & & 2,25 & 11 & 1,7 & 42,075 \\
\hline \begin{tabular}{|l|} 
W9 \\
\end{tabular} & 4,5 & 4,3 & & 19,35 & 11 & 1,7 & 361,845 \\
\hline W10 & 4,5 & 3,2 & & 7,2 & 11 & 1,7 & 134,64 \\
\hline W11 & 2 & 1,2 & & 2,4 & 11 & 1,7 & 44,88 \\
\hline W12 & 2 & 2 & & 4 & 11 & 1,7 & 74,8 \\
\hline TOTAL & & & & & & & 1995,51 \\
\hline
\end{tabular}

Berat Total Abutment dan Tanah dibelakang Abutment

Berdasarkan berat total dari tabel diatas maka pembebanan pada struktur bangunan bawah Jembatan Busur Pemali dapat dilihat pada Tabel 4. [4]. 
Tabel 4.

Pembebanan pada Jembatan Busur Pemali

\begin{tabular}{|c|c|c|c|c|c|c|c|c|}
\hline NO & BEBAN & NOTASI & $\mathrm{V}$ (tono & Hy (ton) & $\mathrm{Hx}$ (Ton) & $\begin{array}{c}\text { lengan } \\
\text { terhadap } \\
\text { titik O } \\
\text { (m) }\end{array}$ & My (tonm) & $\begin{array}{l}\mathrm{Mx} \\
\text { (tonm) }\end{array}$ \\
\hline 1 & $\begin{array}{l}\text { beban Mati } \\
\text { Bangunan Atas }\end{array}$ & A & 2539,0278 & & 0 & 0 & & \\
\hline 2 & \begin{tabular}{|l|} 
Beban Mati \\
Bangunan Bawah + \\
Tanah
\end{tabular} & B & 1995,51 & & & $-0,01816$ & $-36,2380751$ & \\
\hline 3 & \begin{tabular}{|l|} 
Tekanan Tanah \\
Aktif
\end{tabular} & c & & 250,24 & & 4 & 1000,96 & \\
\hline 4 & $\begin{array}{l}\text { Beban Lalu Lintas } \\
\text { + beban Kejut } \\
\text { (DLA) + Beban } \\
\text { Pejalan Kaki } \\
\end{array}$ & D & 748,125 & & & 0 & 0 & \\
\hline 5 & Rem & $E$ & & 23 & & 7,5 & 172,5 & \\
\hline 6 & \begin{tabular}{|l|} 
Gesekan \\
Perletakan Akibat \\
Susut
\end{tabular} & $\mathrm{F}$ & & 0 & & 7,5 & 0 & \\
\hline 7 & Arus & G & & & 0 & 0 & & 0 \\
\hline 8 & Tumbukan & $\mathrm{H}$ & & & 0 & 0 & & 0 \\
\hline 9 & \begin{tabular}{|l|} 
Angin Pada \\
Struktur
\end{tabular} & 1 & & & 2,593 & 7,5 & & 19,4475 \\
\hline 10 & \begin{tabular}{|l|} 
Angin Pada \\
Kendaraan
\end{tabular} & J & & & 3,99 & 7,5 & & 29,925 \\
\hline 11 & $\begin{array}{l}\text { Gempa Pada } \\
\text { Bangunan Atas }\end{array}$ & K & & 146,169 & 146,169 & 7,5 & 1096,2675 & 1096,268 \\
\hline 12 & $\begin{array}{l}\text { Gempa Pada } \\
\text { Bangunan Bawah }\end{array}$ & L & & 183,153 & 183,153 & 3,881719 & 710,9485035 & 710,9485 \\
\hline 13 & $\begin{array}{l}\text { Tekanan Tanah } \\
\text { Akhibat Gempa }\end{array}$ & M & & 322,375683 & & 3,881719 & 1251,371854 & \\
\hline \multicolumn{3}{|c|}{ TOTAL } & 5282,6628 & 924,937683 & 335,905 & 49,24528 & 4195,809782 & 1856,589 \\
\hline
\end{tabular}

Sesuai kontrol geser dan guling abutment serta kontrol tiang pancang sesuai kondisi tanah didapatkan dimensi abutment dengan panjang 11 meter, lebar 11 meter, dan tinggi 10 meter serta tiang pancang dari PT Wijaya Karya sebanyak 36 buah [12].
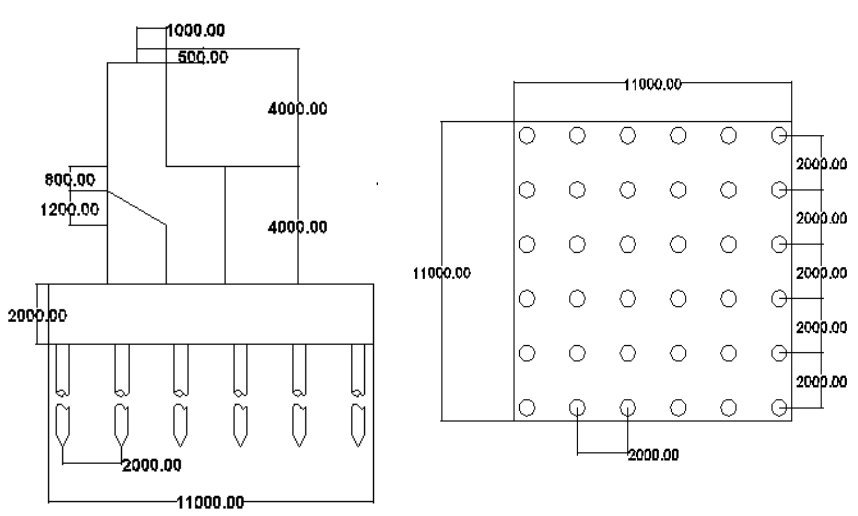

Gambar 11. Desain Abutment dan Konfigurasi Tiang Pancang

\section{KESIMPULAN}

1. Perancanaan pelat lantai kendaraan merupakan pelat beton yang memiliki ketebalan $20 \mathrm{~cm}$ dan dilapisi aspal dengan ketebalan $5 \mathrm{~cm}$.

2. Profil struktur sekunder Jembatan Pemali menggunakan mutu baja BJ 41 dengan fu $=410 \mathrm{Mpa}$ dan fy $=250$ Mpa.

3. Dari hasil perhitungan struktur sekunder jembatan busur didapatkan :

- Profil gelagar memanjang WF 400 x 300 x 10 x 16

- Profil gelagar melintang WF 900 x 300 x 28 x 16

- Ikatan angin lantai kendaraan L 150 x 150 x 16
- Ikatan angin rangka L 200 x 200 x 16

- Ikatan silang angin rangka L 180 x 180 x 16

- Batang horizontal ikatan angin rangka Box 180 x 180 x 8

- Ikatan silang angin lantai kendaraan Box 180 x 180 x 8

4. Perletakaan yang digunakan mengguanakan elastomer dengan ukuran 600 x $600 \mathrm{~mm}$ dengan ketebalan $69 \mathrm{~mm}$.

5. Hasil analisis pada progam SAP2000 penggunaan damper sebagai lateral stopper mempengaruhi pengurangan maksimum sebesar $16 \%$.

6. Abutment jembatan memiliki tinggi 6 meter dan lebar 11 meter dengan lebar poer 11 meter dan tebal 2 meter. mutu beton yang digunakan adalah f'c $40 \mathrm{Mpa}$.

7. Pondasi struktur menggunakan tiang pancang spun pile PT. WIKA BETON dengan diameter $60 \mathrm{~cm}$ (Tipe A1) yang memiliki kedalaman 32 meter sesuai dengan penyelidikan tanah SPT (Standard Penetration Test). Jumlah tiang pancang yang dibutuhkan 36 buah.

\section{DAFTAR PUSTAKA}

[1] Badan Standardisasi Nasional. 1992. Bridge Management System (BMS) Peraturan Perencanaan Teknik Jembatan. Jakarta: Badan Standardisasi Nasional

[2] Badan Standardisasi Nasional. 2002. SNI 03-1729-2002 Standar Perencanaan Struktur Baja untuk Bangunan Gedung. Jakarta: Badan Standardisasi Nasional.

[3] Badan Standardisasi Nasional. 2002. SNI 03-2847-2002 Standar Perhitungan Struktur Beton untuk Bangunan Gedung. Jakarta: Badan Standardisasi Nasional

[4] Badan Standardisasi Nasional. 2005. SNI T-02-2005 Standar Pembebanan untuk Jembatan. Jakarta: Badan Standardisasi Nasional.

[5] Badan Standardisasi Nasional. 2005. SNI 1725-2016 Standar Pembebanan untuk Jembatan. Jakarta: Badan Standardisasi Nasional.

[6] Badan Standardisasi Nasional. 2005. SNI T-03-2005 Standar Perencanaan Struktur Baja untuk Jembatan. Jakarta: Badan Standardisasi Nasional.

[7] Badan Standardisasi Nasional. 2008. SNI 03-2833-2008 Standar Perencanaan Ketahanan Gempa untuk Jembatan. Jakarta: Badan Standardisasi Nasional.

[8] Freyssinet. 2008. Elastomeric Bearings. CE. France.

[9] Harwiyono (alm), Ir., Dr. Ir. Hidajat Sugihardjo, MS., dan Ir. Joko Irawan, MS. 2007. Diktat Kuliah Jembatan Bentang Panjang. Jurusan Teknik Sipil Fakultas Teknik Sipil dan Perencanaan Institut Teknologi Sepuluh Nopember Surabaya.

[10] Marwan dan Isdarmanu. 2006. Buku Ajar Struktur Baja I. Jurusan Teknik Sipil Fakultas Teknik Sipil dan Perencanaan Institut Teknologi Sepuluh Nopember Surabaya.

[11] PT. Gunung Raja Paksi. 2001. Square Hollow Section. Steel Indonesia. Bekasi.

[12] PT. Wijaya Karya. 2007. Tiang Pancang Standart. Wika Beton. Karawang.

[13] Taylor. 1990. Taylor Devices Inc. 90 Taylor Drive. Amerika. 